\title{
Dijital Seyahat Aracıları Marka Değerinin Müşteri E-Tatmini ile İlişkisi
}

\author{
The Relationship of Digital Travel Intermediaries' Brand Equity with Customer E-Satisfaction
}

\author{
Anıl KÜTÜK *, Burcu Selin YILMAZ ** \\ * (Sorumlu Yazar) Doktora Öğrencisi, Dokuz Eylül Üniversitesi, Sosyal Bilimler Enstitüsü, Turizm İşletmeciliği ABD, Dokuz Eylül Üniversitesi, Kaynaklar Yerleşkesi, \\ 35390, Kuruçeşme, Buca, İzmir. \\ E-Posta: anilkutuk89@gmail.com \\ ORCID: 0000-0002-1563-874X \\ ** Prof. Dr., Dokuz Eylül Üniversitesi, İ̧̧letme Fakültesi, Turizm İşletmeciliği ABD, Dokuz Eylül Üniversitesi, Kaynaklar Yerleşkesi, 35390, Kuruçeşme, Buca, İzmir. \\ E-Posta: selin.yilmaz@deu.edu.tr \\ ORCID: 0000-0002-6997-6146
}

MAKALE BILGILERI

Makale işlem bilgileri:

Gönderilme tarihi: 3 Mayıs 2021

Düzeltme: 30 Temmuz 2021

Düzeltme: 14 Eylül 2021

Düzeltme: 30 Eylül 2021

Düzeltme:12 Ekim 2021

Kabul: 22 Ekim 2021

Anahtar sözcükler: Dijital seyahat aracıları, Marka değeri, Müşteri tatmini, E-tatmin.

\section{ARTICLE INFO}

Article history:

Submitted: 3 May 2021

Resubmitted: 30 July 2021

Resubmitted: 14 September 2021

Resubmitted: 30 September 2021

Resubmitted: 12 October 2021

Accepted: 22 October 2021

Key words: Digital travel intermediaries, Brand equity, Customer satisfaction, E-satisfaction.

\begin{abstract}
ÖZ
Bilgi iletișim teknolojilerinin her geçen gün hayatımızdaki rolünün artması ile turizm ve seyahat ișletmeleri de faaliyetlerini internete taşıyarak çevrimiçi platformlara dönüşmüştür. Günümüzde seyahat işletmeciliğini internet ortamına taşıyan dijital seyahat aracıları, icraatlarını çevrimiçi ortamda sürdüren ve seyahat endüstrisinin gelişmesine katkı sağlayan ana unsurlardan biridir. Dijital seyahat aracıları, rakiplerine kıyasla avantaj sağlamak ve marka değerini artırmak için müșteri tatminini yüksek tutmak zorundadır. Bu bağlamda dijital seyahat aracılarının sahip oldukları marka değeri, müşterilerin gözünde fark yaratarak satın alım tercihlerinde önemli rol oynamaktadır. Sahip oldukları güçlü marka değerinin dijital seyahat aracıları müşterilerinin e-tatminine etkisi konusu ise bu çalışmanın problemini oluşturmaktadır. Bu doğrultuda çalışmada, dijital seyahat aracılarının marka değerinin, müşterilerin e-tatminleri üzerindeki etkisinin ölçümüne yönelik bir araştırmaya yer verilmiştir. Ocak, Şubat ve Mart 2021 aylarında herhangi bir dijital seyahat aracısından satın alım yapan toplam 421 katılımcı ile gerçekleștirilen ve yapısal eșitlik modellemesinin kullanıldığı araștırmanın sonucunda marka değerinin alt boyutlarından marka çağrıșımları ve marka sadakatinin e-tatmini pozitif olarak etkilediği belirlenmiştir.
\end{abstract}

\begin{abstract}
With the increasing role of information communication technologies in our lives day by day, tourism and travel businesses have transformed into online platforms by carrying their activities to the internet. Today, digital travel agents, which carry travel business to the internet, are one of the main elements that continue their activities online and contribute to the development of the travel industry. Digital travel brokers have to keep customer satisfaction high in order to gain an advantage over their competitors and increase brand equity. In this context, the brand equity of digital travel agents creates a difference in the eyes of customers and plays an important role in their purchasing preferences. The impact of their strong brand equity on the e-satisfaction of customers of digital travel agents is the problem of this study. Accordingly, the study included a research on measuring the effect of brand equity of digital travel agents on e-satisfaction of customers. As a result of the research conducted with a total of $\mathbf{4 2 1}$ participants who purchased from any digital travel intermediary in January, February and March 2021 and using structural equation modeling, it was determined that brand associations and brand loyalty, which are sub-dimensions of brand equity, positively affect e-satisfaction.
\end{abstract}

\section{Giriş}

Bilgi iletişim teknolojileri ve Web tabanlı teknolojilerin gelişimi hayatımıza birçok yeniliği de beraberinde getirmiştir. Özellikle internetin hayatımızın neredeyse odak noktasına yerleşmeye başladığı 2000'li yıllar ve sonrasında işletmeler de internetten yararlanma konusunda çalışmalara başlamış (Porter 2001) ve internet üzerinden satın alınabilen hemen her şey gibi turistik ihtiyaçlar da internet üzerinden karşılanmaya baş- 
lanmıştır. Turizm endüstrisinin statik ve dinamik aktörleri olarak kabul edilen konaklama ve seyahat işletmeleri de sektörde var olabilmek ve kar oranlarını artırabilmek adına faaliyet gösterdikleri pazarlarda, marka değerlerini artırmaya yönelik adımlar atmaktadır. Diğer yandan müşteri açısından bakıldı ğında ise her geçen gün önemi daha da artan teknoloji odaklı dünyamızda, müşteri karar verme süreçlerinin giderek dijital ortama göre şekillenmeye başladığı görülmektedir. İnternet üzerinden faaliyet yürüten seyahat işletmeleri de müşterilerine uçak bileti, otel rezervasyonu, tatil rezervasyonu, kiralık araç servisi gibi hizmetlerini dijital ortamlarda gerçekleştirerek bilgi arama, alternatiflerin değerlendirilmesi ve satın alım gibi satın alma sürecinin tüm aşamalarında çeşitli hizmetler sunarak, kolaylıklar sağlamaktadır (Gökdemir ve Erdem 2017). Bugün çevrimiçi ortamlarda yer alan olumlu veya olumsuz kullanıcı yorumları müşterilerin satın alma davranışı üzerinde satın alma niyetini belirleyici bir etkiye sahiptir (Sarışık ve Özbay 2012). Dijital seyahat araciları ise tam da bu noktada, bireylerin turistik ihtiyaçlarını tatmin edebilecekleri ve sunulan hizmetleri satın alabilecekleri geniş bir mecra olarak karşımıza çıkmaktadır. Bu mecranın dijital (çevrimiçi) olması, yani müşterilerin direkt muhatap alacakları fiziksel bir ofis, büro vb. ortamin olmaması ve hizmetlerin tamamen internet üzerinden sunulması, marka değerinin olmadığı ya da marka değerinin öneminin azımsanacağ 1 anlamına gelmemektedir. Bu durumun aksine dijital seyahat aracılarının marka değeri oldukça önemlidir. Marka değeri, diğer endüstriyel işletmeler gibi bu işletmeler için de ne pahasına olursa olsun korunması gereken, işletmenin en önemli varlığı konumundadır (Pınar ve Trapp 2010). Korunması gereken bu değerin, dijital seyahat aracılarının müşterilerinin elektronik tatminleri üzerinde etkili olup olmadığı konusu ise bu çalışmanın temel problemini oluşturmaktadır. Bu bağlamda çalışmada, dijital seyahat aracılarının marka farkındalığı, marka sadakati, marka çağrışımları ve algılanan kaliteden oluşan marka değeri alt boyutları ile müşterilerin e-tatmini arasındaki ilişkinin incelenmesi amaçlanmaktadır.
Bugüne kadar marka değeri ve marka değeri bileşenlerinin e-tatmin üzerindeki etkisini belirlemeye yönelik çeşitli araştırmalar ulusal ve uluslararası alanyazında mevcuttur (Bkz. Keller 1993; Lassar vd. 1995; Kim vd. 2006; Masoomeh 2006; Çetin 2009; Kocaman ve Güngör 2012; Matthews vd. 2014; Önen 2017; Quan vd. 2020; Mahadin vd. 2020). Buna karşın dijital seyahat aracıları özelinde marka değerinin müşterilerin e-tatminleri üzerindeki etkisini ölçmeye yönelik bir araştırmanın olmaması, bu çalışmanın bu yönüyle alanyazına yeni ve farklı bir bakış açısı sunarak katkı sağlamasını amaçlamaktadır.

\section{KURAMSAL ÇERÇEVE VE İGILI ÇALIŞMALAR}

Araştırmanın bu bölümünde turizmde dijital seyahat aracıları, marka değeri ve müşteri e-tatminine yönelik alanyazın taraması yapılarak kavramlar arasındaki ilişkileri ortaya koyan öncül araştırmaların sonuçlarına yer verilmiştir. Gerçekleştirilen alanyazın taraması sonucu oluşturulan araştırma hipotezleri ise bu bölümün sonrasinda yer alan yöntem bölümünde aktarılmıştır.

\section{Dijital Seyahat Aracıları ve Marka Değeri}

Ekonominin temel sektörlerinden biri olan turizmde faaliyet göstermesine rağmen herhangi bir fiziksel mekânı olmayan dijital seyahat aracıları için marka değeri hayati önem taşımaktadır. Long ve Shi'ye (2017) göre dijital, diğer bir ifade ile çevrimiçi (online) seyahat aracıları, geleneksel seyahat aracısı işletmelerden farklı olarak hizmetlerini internet ve çevrimiçi platformlar vasıtasıyla sunmaktadır. Dijital seyahat aracılarl, tüketicilere (müşterilere), günün her saatinde hemen her yerde otel odası, ulaşım bileti (uçak, otobüs, tren, gemi) ve araç kiralama gibi turistik hizmetlere ilişkin rezervasyon yapılması, seyahat destinasyonlarına yönelik bilgi sunulması ve bu destinasyonlardaki konaklama alternatiflerinin sunulması hizmetlerini sağlamaktadır. Marka değeri kavramı ise 1990'lı yıllar ile birlikte alanyazında artan bir ilgi ile karşılaşmıştır (Aaker 1991; Simon ve Sullivan 1993; Aaker 1996). Bu doğrultuda en çok kabul gören tanım ise David Aaker (1991) tarafından yapılmıştır. Bu tanımla- 
maya göre marka değeri kavramı, tüketici temelli marka değeri olarak algılanan kalite, marka farkındalığı, marka çağrışımları ve marka sadakatinin toplam sonucu olarak görülmektedir (Aaker 1991). Marka değerine yönelik bu tanımlama tüm sektörler için genel geçer bir tanımlama haline gelmiştir. Bu nedenle turizm sektörü için de marka değeri çalışmaları Aaker'in bu tanımında yer alan alt boyutlar çerçevesinde incelenmektedir. Bu kapsamda tüketici temelli marka değerinin alt boyutlarını oluşturan algılanan kalite; tüketicilerin bir ürünün sahip olduğu üstünlükler hakkında zihinlerinde oluşturdukları yargılardan ibarettir (Zeithaml 1988). Marka farkındalığ 1 boyutu ise tüketicilerin bir markaya ilişkin hafızalarında yer alan işaretler ya da semboller aracılığıyla farklı koşullarda da söz konusu markayı tanıma yeteneğidir (Keller 1993). Bir diğer önemli boyut olan marka çağrışımları, tüketicilerin hafızalarında markayla bağlantılı olan her şey olarak kabul edilmektedir (Aaker 1991). Tüketici temelli marka değerini oluşturan son boyut olarak marka sadakati ise tüketicilerin bir markaya yönelik olumlu düşünceleri ve bu düşüncelerini koruma davranışları arasındaki bağlantının gücü olarak tanımlanmaktadır (Dick ve Basu 1994).

Turizm endüstrisinde marka değeri ile ilgili olarak alanyazında çok sayıda çalışmaya rastlanmakla birlikte dijital seyahat aracılarının marka değeri özelinde herhangi bir çalışmaya rastlanmamaktadır. Ancak marka farkındalığı, algılanan kalite, marka çağrışımları ve marka sadakati konularının ayrı ayrı ele alınarak ölçümlendiği çalışmalara rastlanmaktadır. Aaker'in (1991) tanımlamasında olduğu gibi tüm bu boyutlar birleşerek marka değerini oluşturmaktadır. Örneğin; Khamwon ve Nantasuk (2020) tarafından dünya turizminde önemli bir destinasyon olan Tayland'da gerçekleştirilen bir araştırmada dijital seyahat aracılarının müşterilerinin çevrimiçi müşteri deneyimleri, marka sadakatini artıran bir unsur olarak bulunmuş, çalışmada dijital seyahat aracılarının müşteri deneyimi konusunda iyileştirmelere gitmesi gerektiği önerilmiştir. Müşteri deneyimini iyileştirebilmek için şüphesiz asıl satın alımın gerçekleştirileceği internet sitesinin işlevselliği ön plana çıkmaktadır. Lee ve diğerleri (2017) ABD'de faaliyet gösteren dijital seyahat aracılarının web sitelerinin hizmet verebilirliğini, işlevsel ve teknik hizmet bağlamında incelemiş ve bu iki boyutun dijital seyahat arac1larının müşterilerinin öncelikle müşteri tatminini, sonrasında ise marka bağlılığını olumlu yönde etkilediğini ortaya koymuştur. Kısacası dijital seyahat aracıları için web sitesinin sahip olduğu nitelikler, müşteri tatmini ve marka bağlılığı yaratmanın anahtarı konumundadır.

Marka bağlılığının yarattığı sonuçları inceleyen başka bir çalışma ise Güney Afrika özelinde gerçekleştirilmiş ve dijital seyahat aracılarının müşterilerinin, işletmeye bağlllıkları ile Güney Afrika'daki otellerden satın alma niyeti arasındaki ilişki incelenmiştir (Chivandi vd. 2020). Bu araştırmanın sonucunda, dijital seyahat aracılarının, müşterilerin otele olan bağlllıklarında pozitif rol oynadığı ortaya konmuştur. Bu sonuç da dijital seyahat aracılarının sunduğu hizmetler çerçevesinde bir müşteri tatmini yaratılmasının satın alma niyetini artırması bakımından makro anlamda turizm sektörüne olumlu katkılar sağladığının bir işaretidir. Dolayısıyla dijital seyahat aracılarının marka değeri, müşteri e-tatminini ve tekrar satın alma niyetini artırarak hem kendi karlılığını artırmakta hem de turizm endüstrisinde yer alan diğer aktörlerin hizmet alanlarını genişleterek sektöre olumlu katkı sunmaktadır.

Yukarıda bahsedilen çalışmalardan da görüldüğü üzere dijital seyahat aracılarının sahip olduğu marka değeri, kendisine olduğu kadar sektörün gelişimine de katkı sunmaktadır. Bu değerin yaratılmasında, dijital seyahat aracılarının müşterilerinin e-tatmini de kritik bir noktada bulunmaktadır. Bu bağlamda dijital seyahat aracılarında müşteri e-tatminini de incelemek gerekmektedir.

\section{Dijital Seyahat Aracılarında Müşteri E-Tatmini}

Dijital seyahat aracıları her ne kadar fiziksel bir ortama sahip olmasalar da ticari amaçlarla faaliyet yürüten işletmeler olarak hizmetlerini internet üzerinden sunmaktadır. Bu doğrultuda hizmet sektörü işletmesi olan dijital seyahat aracıları için müşterilere hizmetin sunulduğu çevrimiçi mecralarda müşteri tatmininin sağlanması başarının anahtarıdır. Alanyazında dijital seyahat 
aracılarının müşterilerinin e-tatminine yönelik gerçekleşen bazı araştırmaların bulguları incelendiğinde, müşteri tatmininin ya da tatminsizliğinin, fiziksel işletmelerde olduğu gibi satın alım davranışını etkilediği görülmektedir.

Ting ve diğerleri (2013) tarafından gerçekleştirilen bir çalışmada, dijital seyahat aracılarında müşteri tatmininin, hizmet kalitesinden doğrudan etkilendiği ve satın alım niyeti üzerinde pozitif bir etki yarattı̆̆ 1 görülmektedir. Benzer şekilde, dijital seyahat aracilarının web sitelerinde sunduğu hizmet kalitesinin e-tatmin üzerinde önemli ölçüde etkili olduğunu ortaya koyan Niu ve Lee (2018), müşterilerde e-tatmini sağlayan unsurların web sitesinin güvenliği ve dijital seyahat aracısının güvenilirliği olduğu sonucuna ulaşmıştır. Bir başka çalışmada ise Kourtesopoulou ve diğerleri (2019), dijital seyahat aracılarında web sitelerinin kullanım kolaylığ 1 ve sitelerin yanıt verme hızının, müşteri tatmini sağlamada en önemli unsurlar olduğunu ortaya koymuştur.

Dijital seyahat aracılarında müşteri tatmininin, satın alma niyetini olumlu etkileyerek satışları artırdığını söylemek mümkün olmakla birlikte, bu tatmini sağlayan faktörlerin ne olduğunu ortaya koymak üzere de çeşitli araştırmaların gerçekleştirildiği görülmektedir. Örneğin Dutta ve diğerleri (2017), Hindistan'daki dijital seyahat aracıları müşterilerinin e-tatminlerini etkileyen faktörleri incelemiştir. Bu kapsamda dijital seyahat aracilarından beklentilerin ve hizmet kalitesinin algılanan değerinin, müşteri tatminini etkilediği ve bu durumun da daha az şikâyet ve daha yüksek bağlılık ile ilişkili olduğu sonucuna varılmıştır. Başka bir çalışmada ise Tseng (2017), çevrimiçi hizmet satın alan turistlerin, satıcıların puanlarına ihtiyaç duyma nedenlerini ve bunun da memnuniyet ile olan ilişkisini incelemiştir. Araştırmanın sonucunda, satıcı değerlendirmelerinde tatmin olmayan turistlerin e-tatminlerini artırmanın önemi ortaya konmuştur.

Doğrudan dijital seyahat aracıları ile ilgili olmamakla birlikte turizmde müşteri tatmini ve marka değeri boyutlarının birbirleri ve müşteri sadakati ile ilişkilerini ölçümleyen bazı çalışmalar da alanyazında mevcuttur. Örneğin; Mahadin ve diğerleri (2020) Ürdün'e seyahat eden 258 ABD vatandaşı ile gerçekleştirdikleri araştırmada, tatmin ile sadakat arasındaki pozitif yönlü ilişkiyi ortaya koymuştur. Azhar ve diğerleri (2019) tarafından yapısal eşitlik modellemesi kullanarak gerçekleşen araştırmanın sonucunda, algılanan kalitenin de turistlerin e-tatmini üzerinde pozitif etkisi olduğu belirlenmiştir.

San Martin ve diğerleri (2019) tarafından gerçekleştirilen bir başka çalışmada ise turizmde marka değerinin müşterilerin e-tatmini üzerindeki etkisi ölçülmüştür. 251'i yerli, 416's1 yabanc1 toplam 667 turist ile gerçekleştirilen bu araştırmanin sonucunda, hem yerli hem de yabanc1 turistler için marka değerinin müşteri tatmini ile pozitif yönlü ilişkisi ortaya konmuştur. Liu ve Fang (2018) da 348 yabancı turist ile gerçekleştirdiği araştırma sonucunda, algılanan kalite boyutunun marka farkındalığı yarattığını, marka farkındalığının da marka sadakati ve marka imajı aracılığ 1 ile tatmini sağladığını benzer şekilde ortaya koymuştur.

Görüldüğü üzere turizmde marka değeri ve müşteri tatminine yönelik çalışmaların sıklıkla gerçekleştirilmesine rağmen dijital seyahat arac1ları özelinde hem marka değeri hem de müşterilerin e-tatminlerine ilişkin araştırmaların sınırlı sayıda olduğunu söylemek mümkündür. Bu çalışmalar ise doğrudan marka değeri ile ilgili olmayıp, tümü marka değerini oluşturan alt boyutlarla ilişkilidir. Bu kapsamda bu çalışmanın, dijital seyahat aracılarında marka değerinin müşterilerin e-tatmini özelinde inceleyen öncü çalışmalardan biri olması bakımından ilgili alanyazına katkı sağlayacağı öngörülmektedir.

\section{YÖNTEM}

Bu kısımda dijital seyahat aracılarında marka değerinin e-tatmin üzerindeki etkisine yönelik tarafımızca gerçekleştirilen araştırmanın yöntem bilgisine yer verilmiştir.

\section{Araştırmada Kullanılan Veri Toplama Araçları}

Bu çalışmada turistik ürünleri satın alırken dijital seyahat aracılarını tercih eden müşterilere yönelik hazırlanan bir anket çalışmasına yer verilmiştir. Oluşturulan anket formunda marka değerini ölçümlemek üzere Yoo ve diğerleri (2000) 
tarafından geliştirilen "Tüketici Temelli Marka Değeri Ölçeği"'nden yararlanılmıştır. Müşteri e-tatminini ölçümlemek üzere ise Anderson ve Srinivasan (2003) ve Chung ve Shin'in (2008) çalışmalarında yer alan e-tatmine yönelik ölçekler, dijital seyahat aracılarına uyarlanarak kullanılmıştır. Bu bağlamda ölçeklerin güvenilirliğini ölçmek için kullanılan Cronbach Alpha güvenilirlik değeri 0,60 ile 0,80 arasında ise ölçeğin orta güvenilir, 0,80 ile 1,00 arasında ise ölçeğin yüksek güvenilir olduğunu göstermektedir (Kayış 2009). Bu doğrultuda yararlanılan Yoo ve diğerlerinin (2000), "Tüketici Temelli Marka Değeri Ölçeği" nde Cronbach Alpha güvenilirlik değerleri sırasıyla; algılanan kalite için 0,93, marka sadakati boyutu için 0,90 , marka farkındalığ $\breve{1}_{1}$ ve marka çağrışımları boyutları için ise 0,94 olarak hesaplanmıştır. Chung ve Shin (2008)'in ölçeğinde, e-tatminin Cronbach Alpha güvenilirlik değeri 0,935 , Anderson ve Srinivasan (2003)'ın ölçeğinde ise 0,8947 olarak belirlenmiştir.

\section{Araştırma Modeli}

Araştırmada iki değişken arasındaki ilişkinin ortaya konulması amacıyla Yapısal Eşitlik Modellemesinden (YEM) faydalanılmıştır. Yapısal eşitlik modellemesi, sosyal bilimlerde doğrudan ölçülemeyen soyut yapıların araştırılmasında kullanılan, doğrudan ölçülemeyen gizil yapıları gözlenen değiş̧kenler aracılığı ile incelemeye yardımcı olan tekniklerin genel adıdır (Yılmaz ve Varol 2015). Yine yapısal eşitlik modellemesi, faktör analizini, korelasyonu ve değişkenler arasındaki nedensellik ilişkilerini ortaya koyması bakımından çoklu regresyon analizini içermektedir (İlhan ve Çetin 2014). Araştırma kapsamında yapısal eşitlik modellemesi, bağımlı değişken üzerinde bağımsız değişkenin etkisini incelerken bağımsız değişkenin alt boyutlarını da sürece dahil etmesi nedeniyle tercih edilmiştir. Zira yapısal eşitlik modellemesi, fazla sayıda değişkenin dahil edildiği karmaşık modellerde regresyon analizinden daha başarılı olup analizi tek bir seferde tamamlaması, birden fazla analiz tekniğini içermesi ve ölçüm hatalarını hesaba katması gibi nedenlerle regresyon analizine üstünlük sağlamaktadır (Alkış 2016).

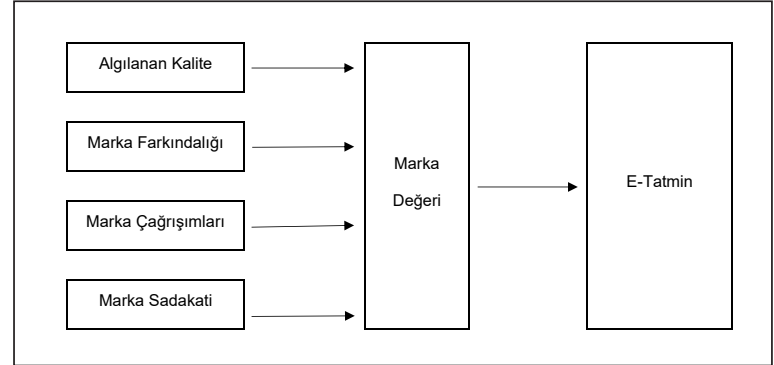

Şekil 1. Araştırma Modeli

Araştırma kapsamında oluşturulan model yukarıdaki şekildeki gibidir.

Model kapsamında aşağıdaki hipotezler oluşturulmuştur:

$\mathrm{H}_{1}$ : Dijital seyahat aracılarının marka değeri ile müşteri e-tatmini arasında pozitif ilişki bulunmaktadır.

$\mathrm{H}_{1 a}$ : Algılanan kalite ile marka değeri arasında pozitif ilişki bulunmaktadır.

$\mathrm{H}_{1 b}$ : Marka farkındalığı ile marka değeri arasında pozitif ilişki bulunmaktadır.

H1c: Marka çağrışımları ile marka değeri arasında pozitif ilişki bulunmaktadır.

H1d: Marka sadakati ile marka değeri arasında pozitif ilişki bulunmaktadır.

\section{Evren ve Örneklem, Veri Seti ve Verilerin Analizi}

Araştırma evrenini son bir yıl içinde ülkemizde faaliyet gösteren tüm dijital seyahat aracıları arasından herhangi birinden hizmet satın almış tüm müş̧teriler oluşturmaktadır. Bu denli büyük bir örnekleme erişebilmenin hem zaman hem de maddi imkânsızlığı nedeniyle örnekleme yoluna gidilmiş, araştırma son üç ay içerisinde $X, Y$ ve $\mathrm{Z}$ harfleri ile kodlanan işletmelerden (dijital seyahat aracılarından) hizmet satın alan müşteriler ile sınırlandırılmıştır. Araştırmanın tüm aşamalarında bilimsel yazım kurallarına ve etik ilkelere bağlı kalınmıştır. Araştırmanın verilerinin toplanması için gereken Etik Kurul Onayı, Dokuz Eylül Üniversitesi Sosyal ve Beşeri Bilimler Araştırma ve Yayın Etik Kurulu'ndan, 12.02.2021 tarihinde E-57485104-300,99-15774 sayılı başvuru sonucunda 15.03.2021 tarihli toplantıda alınan 7 sayılı karar sonucu alınmıştır. İmzalı Etik Kurul 
Onayı belgesi, çalışma dergiye önerilirken yazarlar tarafından ibraz edilmiştir. Araştırmanın uygulama sürecinde hazırlanan anket formları, çevrimiçi ortamda Google Forms yazılımı aracilığıyla oluşturulmuştur. Bu doğrultuda oluşturulan link, hedef kitle olan özellikle daha önce çeşitli turlara birlikte katılan ve sık seyahat eden katılımciların (seyahat grupları) bulundugu WhatsApp ve Facebook gruplarına mesaj ve e-posta yolu ile iletilmiştir. Araştırmanın Google Forms anketinde katılımcılara bir ön eleme sorusu sorulmuştur. İlgili soru ise "Daha önce dijital seyahat aracılarından alışveriş yaptınız mı?" şeklinde sorulmuştur. Bu soruya verilen yanitlardan "Hayır" seçeneği seçildiğinde, Google Forms anket sistemi, ilgili katılımcıyı hedef kitleye uygun olmadığı gerekçesiyle araştırmadan çıkarmıştır. Kolayda örnekleme yöntemi ile toplanan veriler 15-30 Mart 2021 tarihleri arasında toplanmıştır. İlgili tarihler arasında, son üç ay içerisinde (Ocak, Şubat ve Mart 2021 tarihlerinde) dijital seyahat aracılarından hizmet satın almış 500 kişiye ulaşılmiştır. Bu doğrultuda ön eleme sorusunda hayır cevabını işaretleyerek ankete katılamayan ve sistem dışı kalan 16 katılımcı (yüzde 3,2) ile, anketin tümünü tamamlamayan ya da özensiz bir şekilde yanıtladığ 1 tespit edilen 63 (yüzde 12,6) katılımcının anket formları bu süreçte elenmiştir. Sonuç olarak 421 (yüzde 84,2) katılımcının verileri araştırmaya dahil edilmiş ve analizler gerçekleştirilmiştir. Verilerin analizlerinde SPSS for Windows v26.0 ve IBM AMOS v24.0 paket programlarından faydalanılmıştır.

\section{BULGULARIN YORUMLANMASI}

Araştırmanın bu bölümünde gerçekleşen uygulama sonrası katılımcılardan sağlanan verilerin analizlerinden elde edilen detaylı bulgulara yer verilmiştir.

\section{Betimleyici İstatistikler}

Tablo 1'de katılımcıların demografik özellikleri görülmektedir. Buna göre katılımcıların yüzde 57,3'ü kadın, yüzde 42,7'si ise erkektir. Katılımc1ların yüzde 8,7' si 18-24 yaş aralığında yer alırken, yüzde $34,2^{\prime}$ si 25-34 yaş aralığında, yüzde 37,8'i $35-44$ yaş aralığında yüzde $16,4^{\prime}$ ü ise $55-64$ yaş aralığındadır. 65 yaşın üzerindeki katılımcıların oranı ise yüzde 2,9'dur. Son olarak katılımcıların yüzde 10,2'si lise ve öncesi öğrenim düzeyine sahipken, yüzde 16,9'u ön lisans, yüzde 58,2'si lisans, yüzde 10,2'si yüksek lisans ve yüzde 4,5'i doktora mezunudur.

Tablo 2'de marka değerinin alt boyutları olan algılanan kalite, marka farkındalığı, marka çağrışımları ve marka sadakati ile e-tatmine ilişkin betimleyici istatistikler, basıklık ve çarpıklık değerleri ile Cronbach Alpha değeri görülmektedir. Marka değerinin alt boyutlarına ait Cronbach Alpha değerlerinin güvenilir sonuçlar verebilmesi için 0,700'den büyük olması gereklidir (Gürbüz ve Şahin 2016). Boyutlara ilişkin Cronbach Alpha değerlerinin de tüm boyutlar için 0,700 'den büyük olduğu görülmektedir. Dolayısıyla ölçeğin oldukça güvenilir sonuçlar verdiğini söylemek mümkündür.

Aynı zamanda verilerin normal dağılıma uygunluğunun tespit edilmesi amaciyla basıklık ve çarpıklık değerleri de Tablo 2'de görülmektedir. Bir veri setinin normallik varsayımlarını karşılaması için basıklık ve çarpıklık değerleri -2 ile +2 aralığında olmalıdır (Gürbüz ve Şahin 2016). Boyutlara ilişkin ilgili değerler incelendiğinde, bu değerlerin limit değerler aralığında olduğu, dolayısıyla verilerin normal dağılım gösterdiği görülmektedir.

\section{Marka Değerinin E-Tatmin Üzerindeki Etkisi}

Şekil 2'de marka değerinin e-tatmin üzerindeki etkisini ortaya koymak üzere oluşturulan model, Tablo 3'te ise modele ilişkin uyum indeksleri görülmektedir. Model uyum indeksleri incelendi-

Tablo 1. Demografik Özellikler

\begin{tabular}{|c|c|c|c|c|c|c|c|c|}
\hline & $n$ & Yüzde & & $n$ & Yüzde & & $n$ & Yüzde \\
\hline Cinsiyet & & & Yaş & & & Öğrenim Durumu & & \\
\hline Erkek & 180 & 42,7 & $18-24$ & 37 & 8,7 & Lise ve Öncesi & 43 & 10,2 \\
\hline \multirow[t]{4}{*}{ Kadın } & 241 & 57,3 & $25-34$ & 144 & 34,2 & Ön Lisans & 71 & 16,9 \\
\hline & & & $35-44$ & 159 & 37,8 & Lisans & 245 & 58,2 \\
\hline & & & $55-64$ & 69 & 16,4 & Yüksek Lisans & 43 & 10,2 \\
\hline & & & 65 ve Üzeri & 12 & 2,9 & Doktora & 19 & 4,5 \\
\hline Toplam & 421 & 100,0 & Toplam & 421 & 100,0 & Toplam & 421 & 100,0 \\
\hline
\end{tabular}




\begin{tabular}{|c|c|c|c|}
\hline Marka Değeri & & $x$ & SS \\
\hline Kalite (a) & $\begin{array}{l}\text { Markası, kendisini açık bir şekilde diğer markalardan ayıran bir } \\
\text { kimliğe sahiptir. }\end{array}$ & 3,88 & 1,075 \\
\hline Kalite (b) & $\begin{array}{l}\text { Benzer markalara kıyasla müşterilerine kaliteli bir üslup ile ilgili } \\
\text { ve kibar yaklaşmaktadır. }\end{array}$ & 4,01 & 1,093 \\
\hline Kalite (c) & Markası, kanaatimce kendi sınıfında kalite lideridir. & 3,98 & 1,110 \\
\hline Farkındalık (a) & Marka bilinirliği bakımından rakiplerinin önündedir. & 3,84 & 1,006 \\
\hline Farkındalık (b) & $\begin{array}{l}\text { Site tasarımı ve reklamları marka farkındalığı bakımından } \\
\text { etkilidir. }\end{array}$ & 3,99 & 1,091 \\
\hline Farkındalık (c) & $\begin{array}{l}\text { Tüm dijital seyahat aracıları düşünüldüğünde ilk akla gelen, } \\
\text { bilinen bir markadır. }\end{array}$ & 3,95 & 1,123 \\
\hline Çağrışım (a) & $\begin{array}{l}\text { Marka logosu, sembolü veya sloganı, nerede görülse, anında } \\
\text { anımsanır. }\end{array}$ & 3,91 & 0,942 \\
\hline Çağrışım (b) & Markası kendimi değerli hissettirir, benzersizdir. & 3,95 & 1,108 \\
\hline Çağrışım (c) & $\begin{array}{l}\text { Markasının temsilcisi olan, ünlü sanatçıyı } \\
\text { gördüğümde/duyduğumda anında markayı hatırlarım. }\end{array}$ & 3,83 & 1,152 \\
\hline Sadakat (a) & Markasına sadakat gösteririm. & 3,79 & 0,971 \\
\hline Sadakat (b) & Markasını başkalarına da tavsiye ederim. & 3,94 & 1,113 \\
\hline Sadakat (c) & Markasının bir müşterisi olmaktan onur duyarım. & 3,96 & 1,126 \\
\hline Tatmin (a) & Web sitesinde yer alan tekliflerden memnunum. & 3,82 & 0,899 \\
\hline Tatmin (b) & Web sitesinden gerçekleştirdiğim satın alımlardan memnunum. & 3,94 & 0,985 \\
\hline Tatmin (c) & Web sitesinde yer alan ürünlerden memnunum. & 3,93 & 1,071 \\
\hline Tatmin (d) & $\begin{array}{l}\text { Web sitesinden tekrar satın alım yapacak olsam, kendimi farklı } \\
\text { hissederim. }\end{array}$ & 3,50 & 1,057 \\
\hline Tatmin (e) & $\begin{array}{l}\text { Web sitesinden satın alım kararı verdiğim için kendimi kötü } \\
\text { hissederim }\end{array}$ & 3,90 & 1,489 \\
\hline
\end{tabular}


Tablo 2. Betimleyici İstatistikler (Devam)

\begin{tabular}{lccccc}
\hline & $X$ & SS & Basıklık & Çarpıklık & Cronbach's Alpha \\
\hline Algılanan Kalite & 3,9557 & 1,02722 & $-1,383$ & 1,128 & 0,934 \\
Marka Farkındalığı & 3,9232 & 0,99797 & $-1,367$ & 1,048 & 0,920 \\
Marka Çağrışımları & 3,8987 & 0,98253 & $-1,256$ & 0,764 & 0,906 \\
Marka Sadakati & 3,8987 & 0,99191 & $-1,295$ & 0,804 & 0,915 \\
\hline Tatmin & 3,8185 & 0,90540 & $-1,329$ & 0,962 & 0,868 \\
\hline
\end{tabular}

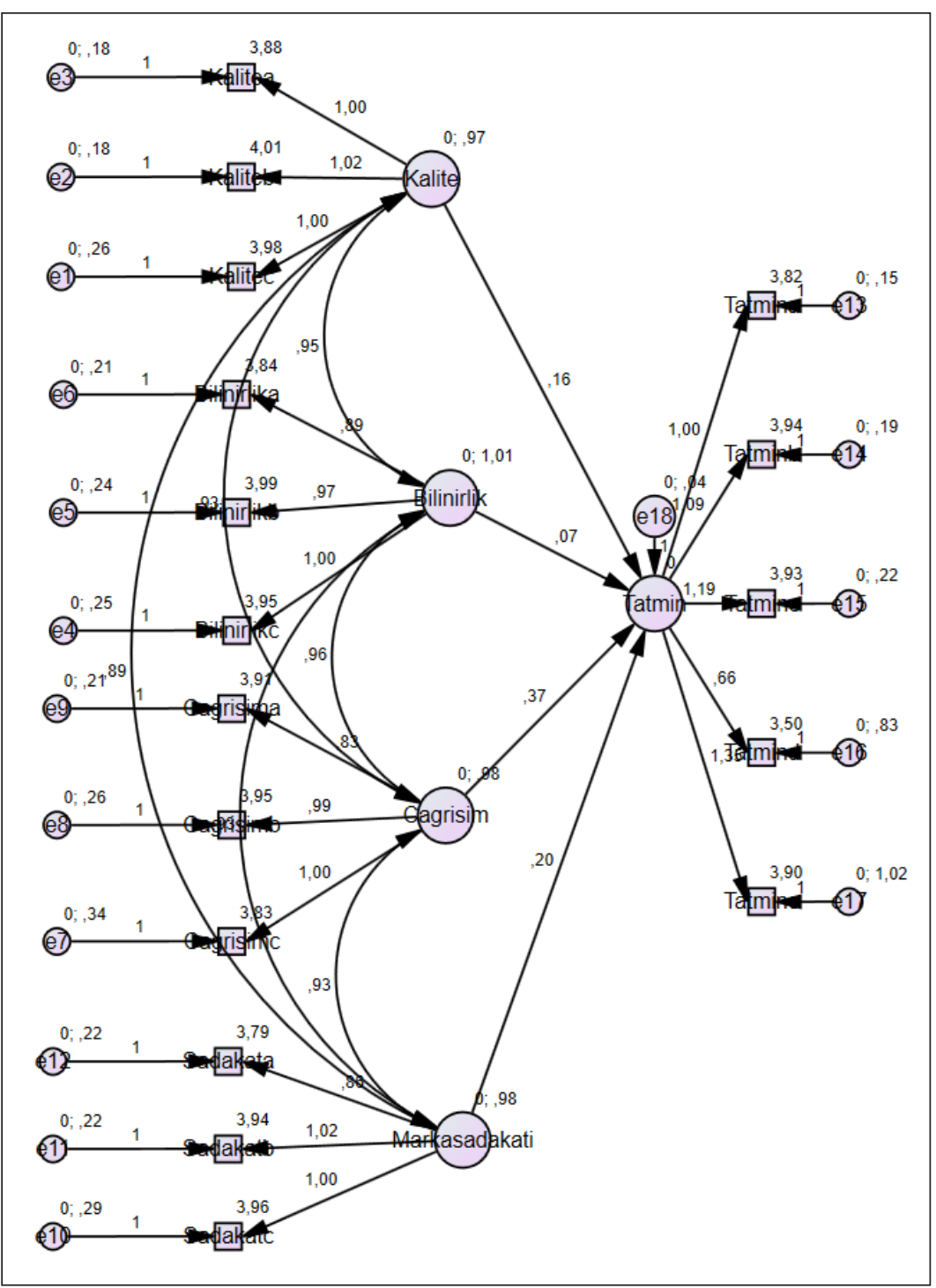

Şekil 2. Marka Değerinin E-Tatmin Üzerindeki Etkisi ğinde $X^{2}$ /sd değerinin 2,486 olarak hesaplandığ 1 ve bu değerin uyum açısından oldukça iyi olduğu görülmektedir. Modele ilişkin RMSEA değeri 0,059 olarak gerçekleşmiştir ve bu değer kabul edilebilir sınırlar içerisindedir. NFI değeri 0,967 olarak CFI değeri ise 0,980 olarak hesaplanmıştır ve bu iki değerin de model uyum indeksinin kabul edilebilirliği bakımından oldukça iyi olduğu görülmektedir. Bu da modelin uyumlu olduğunu ortaya koymaktadır.

Modelin uyumluluğunun ortaya konulmasinın ardından regresyon katsayılarının anlamlı olup olmadığı yapısal eşitlik modeli ile test edilmiştir. Yapılan analiz sonucunda marka değerini oluşturan boyutlardan, marka farkındalığı ve algilanan kalitenin e-tatmin üzerinde pozitif etkisi olduğu görülmüş ancak bu etki istatistiksel olarak anlamlı bulunmamıştır. Bu nedenle oluşturulan hipotezlerden $\mathrm{H}_{1 a}$ ve $\mathrm{H}_{1 b}$ hipotezleri reddedilmiştir. Bu-

Cilt $33 \bullet$ Sayı $1 \bullet$ Bahar $2022 \bullet 63$ 
Tablo 3. Model Uyum İndeksleri

\begin{tabular}{llll}
\hline Model Uyum indeksleri & Hesaplanan & Kabul Edilebilir & iyi / Çok lyi \\
\hline $\mathrm{X}^{2} / \mathrm{sd}$ & 2,486 & $0<\mathrm{X}^{2} / \mathrm{sd}<5$ & $0<\mathrm{X}^{2} / \mathrm{sd}<3$ \\
\hline RMSEA & 0,059 & $0,00 \leq \mathrm{RMSEA} \leq 0,10$ & $0,00 \leq \mathrm{RMSEA} \leq 0,05$ \\
\hline $\mathrm{NFI}$ & 0,967 & $0,90 \leq \mathrm{NFI} \leq 1,0$ & $0,95 \leq \mathrm{NFI} \leq 1,0$ \\
\hline $\mathrm{CFI}$ & 0,980 & $0,90 \leq \mathrm{CFI} \leq 1,0$ & $0,95 \leq \mathrm{CFI} \leq 1,0$ \\
\hline
\end{tabular}

Tablo 4. Standardize Katsayılar ve Anlamlılık

\begin{tabular}{|c|c|c|c|c|}
\hline Marka Değeri & & & Katsayı & $p$ \\
\hline Tatmin & $<--$ & Algılanan Kalite & 0,196 & 0,125 \\
\hline Tatmin & $<--$ & Marka Farkındalığı & 0,089 & 0,579 \\
\hline Tatmin & $<--$ & Marka Çağrışımları & 0,459 & 0,012 \\
\hline Tatmin & $<---$ & Marka Sadakati & 0,240 & 0,027 \\
\hline Kalite (c) & $<--$ & Kalite & 0,887 & \\
\hline Kalite (b) & $<---$ & Kalite & 0,921 & *** \\
\hline Kalite (a) & $<---$ & Kalite & 0,918 & *** \\
\hline Farkındalık (c) & $<--$ & Marka Farkındalığı & 0,896 & \\
\hline Farkındalık (b) & $<---$ & Marka Farkındalığı & 0,893 & *** \\
\hline Farkındalık (a) & $<--$ & Marka Farkındalığı & 0,888 & **** \\
\hline Çağrışım (c) & $<--$ & Çağrışım & 0,862 & \\
\hline Çağrışım (b) & $<--$ & Çağrışım & 0,890 & *** \\
\hline Çağrışım (a) & $<--$ & Çağrışım & 0,876 & **** \\
\hline Sadakat (c) & $<--$ & Marka sadakati & 0,880 & \\
\hline Sadakat (b) & $<--$ & Marka sadakati & 0,909 & *** \\
\hline Sadakat (a) & $<--$ & Marka sadakati & 0,876 & *** \\
\hline Tatmin (a) & $<---$ & Tatmin & 0,899 & \\
\hline Tatmin (b) & $<--$ & Tatmin & 0,895 & *** \\
\hline Tatmin (c) & $<---$ & Tatmin & 0,897 & *** \\
\hline Tatmin (d) & $<--$ & Tatmin & 0,501 & *** \\
\hline Tatmin (e) & $<--$ & Tatmin & 0,735 & **** \\
\hline
\end{tabular}

na karşılık marka çağrışımları ve marka sadakati boyutlarının ise e-tatmini istatistiksel olarak anlamlı bir şekilde $(\mathrm{p}<0,05)$ pozitif etkilediği görülmüştür. Bu nedenle $\mathrm{H}_{1 c}$ ve $\mathrm{H}_{1 \mathrm{~d}}$ hipotezleri kabul edilmiştir. Dolayısıyla dijital seyahat aracılarında marka değerinin e-tatmini olumlu etkilediğine yönelik yeterli kanıt bulunduğundan, “ $\mathrm{H}_{1}$ : Dijital seyahat aracılarının marka değeri ile müşteri e-tatmini arasında pozitif ilişki bulunmaktadır" hipotezi kısmen kabul edilmiştir.

\section{TARTIŞMA SONUÇ VE ÖNERILER}

Bacasız sanayi olarak bilinen turizm sektörü, neredeyse tamamen misafir (müşteri) memnuniyetine duyarlı bir sektördür. Özellikle tatil amaçlı olarak seyahat satın alan müşteriler için bütün yılın yorgunluğunu atabilmek, baştan sona sorunsuz bir tatil süreci ve yaşanılan turistik deneyimden tatmin olma koşuluyla mümkündür. Market alışverişlerinin dahi internet ortamına taşındı günümüzde doğal olarak turizm sektörü de faaliyetlerini internete taşımış ve geleneksel turizm acentelerinin birçoğu dijital seyahat aracılarına dönüşmüştür. Fiziksel ofislerinin bulunmaması durumu, dijital seyahat aracilarının tatmin olan müşteri deneyimi yaşatma adına geleneksel seyahat acentelerinden farklı stratejiler geliştirmeleri gerekliliğini de beraberinde getirmiştir. Bu durum ise müşteri tatmini sağlamak adına bu işletmeler için marka değeri konusunun ne denli önemli olduğunu açıkça ortaya koymaktadır.

Marka değeri, tüketici temelli olarak ele alındığında marka sadakati, marka farkındalığı, algılanan kalite ve marka çağrışımlarının toplam sonucunu yansıtmaktadır. Müşterilerin, turizm ürünlerini satın almak için dijital seyahat arac1larının ofisi yerine, sadece internet sitelerine giriş yaptıkları düşünüldüğünde, müşteri tatmininin sağlanması, internet üzerinden pratik ve kusursuz bir alışveriş deneyiminin yaşatılmasına bağlıdır. Ancak müşterilerin internet üzerinden alışveriş yapmaları için öncelikle dijital seyahat aracılarının internet sitelerini veya mobil uygulamalarını kullanmaları gerekmektedir. Bu da etkin ve güçlü bir marka değeri sayesinde mümkün olmaktadır. 
Bu çalışmada, dijital seyahat aracılarında marka değerinin müşterilerin e-tatmini üzerindeki etkisini belirlemek üzere yapısal eşitlik modelinin uygulandığı bir araştırmaya yer verilmiştir. Araştırmadan elde edilen bulgular doğrultusunda oluşturulan araştırma hipotezi (H1) desteklenmiştir. Bu bağlamda marka değerinin alt boyutları olan marka çağrışımları ve marka sadakati unsurlarının müşteri e-tatminini pozitif etkilediği ortaya konmuştur. Bu doğrultuda araştırmanın, öncül araştırmalara kıyasla fark yaratarak ilgili alanyazına katkı sağladığı düşünülmektedir.

Alanyazında yer alan çalışmalar incelendiğinde, doğrudan dijital seyahat aracıları marka değerinin müşterilerin e-tatmini üzerindeki etkisini belirlemeye yönelik bir araştırmaya rastlanmamaktadır. Buna rağmen marka değerinin alt boyutlarını ayrı ayrı değişkenler olarak ele alarak tatminle arasındaki ilişkiyi ölçen benzer ve farklı sonuçlara ulaşan bazı araştırmalar göze çarpmaktadır. Bu doğrultuda çalışmadan elde edilen bulgular ışığında, marka değerinin ve bazı alt boyutlarının müşteri e-tatminini pozitif etkilemesi durumu alanyazındaki bazı öncül araştırma sonuçlarını destekler niteliktedir (San Martin vd. 2019; Mahadin vd. 2020). Diğer yandan dijital aracıları özelinde hem marka sadakati hem de marka çağrışımları boyutunun e-tatmini pozitif yönde etkilemesi ise bu çalışmayı önceki bazı çalışmalardan (Liu ve Fang 2018; Azhar vd. 2019) ayırmaktadır. Bu minvalde yine araştırma bulguları 1şığında turistik ürünün sunulduğu fiyat, alınan hizmet karşısında hissedilen duygular, yaşanan olumlu tecrübeler ve satın alınan hizmetin müşteriye yarar sağlaması gibi diğer konular da müşterilerin e-tatminini doğrudan etkilemektedir.

Araştırmadan elde edilen sonuçlar çerçevesinde, marka değeri ve müşterilerin e-tatminini artırmak adına dijital seyahat aracıları ve politika yapıcılar tarafından bazı adımların atılması önerilmektedir. Bu doğrultuda aşağıdaki adımlar atılabilir;

- Web site performansı düzenli olarak denetlenmeli ve performansın iyileştirilmesi adına gerekli adımlar atılmalı,
- Dijital seyahat aracilarının ilgili birimlerinde görev alan çalışanların müşterilerle iletişimlerinin geliştirilmesine ilişkin eğitimler desteklenmeli,

- Müşterilerin yaşayabilecekleri olumsuzluk ve memnuniyetsizliklerin işletmeye iletilmesi teşvik edilmeli ve müşteri deneyimleri sonrası memnuniyet anketleri düzenlenmeli,

- Müşteriler tarafından iletilen memnuniyetsizliklerin çözülmesi adına çalışanlar ivedi olarak hareket ederek nazik bir üslupla konuya yaklaşmalı,

- Muhtemel kriz durumlarında müşteri odaklı, proaktif yaklaşımlarda bulunulmalı. Örneğin; dünyada etkisi halen süren Covid-19 pandemisi gibi kritik bir dönemde önceden yapılan rezervasyonların iptali ve ödemelerin iade edilmesi gibi kolaylıklar sağlanmalı,

- Benzer şekilde Covid-19 pandemisi gibi olağanüstü dönemlerde işletmelerin ücret iadesi gibi maddi güç gerektiren faaliyetleri rahatlıkla sürdürebilmesi için politika yapıcılar tarafından bu işletmelerin maddi olanakları desteklenmeli, gerekirse kamu kurumları veya bankalar aracılığı ile sorunların çözümüne katkı sağlayacak finansal destek adımları da atılmalıdır.

Tüm bu adımların atılması, dijital seyahat aracllarından herhangi bir zamanda yararlanan müşterilerin sadık müşterilere dönüşümünü sağlamak adına oldukça önemlidir. Oluşacak sadık müşterilerin ise, yaşadıkları olumlu deneyimler sayesinde, dijital seyahat aracılarına daha fazla güven duyan, fiyata daha az duyarlı, marka çağrışımları yaratan hizmetlerden daha fazla yararlanma arzusuna sahip müşteriler olarak, müşteri e-tatminini artırmanın önemli bir unsuru olacağını söylemek mümkündür.

Son olarak, araştırma sonucunda elde edilen tüm bulgular ışığında bu çalışmanın dijital seyahat aracıları marka değerinin, müşterilerin e-tatminleri üzerindeki etkisini ölçümleyen yeni bir araştırma olması bakımından, alanyazındaki boşluğu doldurarak sektörde yer alan işletmelerin yanı sıra gelecekteki akademik çalışmalar için de 1 şık tutacak bir kaynak oluşturacağ 1 öngörülmektedir. 


\section{KAYNAKÇA}

Aaker, D. A. (1991). Managing Brand Equity. New York: Free Press.

Aaker, D. A. (1996). Measuring Brand Equity Across Products and Markets, California Management Review, 38 (3): 102-120.

Alkış, N. (2016). Bayes Yapısal Eşitlik Modellemesi: Kavramlar ve Genel Bakış, Gazi Journal of Economics and Business, 2 (3): 105-116.

Anderson, R. E. ve Srinivasan, S. S. (2003). E-Satisfaction and E-Loyalty: A Contingency Framework, Psychology ve Marketing, 20 (2):123-138.

Azhar, M. E., Jufrizen, J., Prayogi, M. A. ve Sari, M. (2019). The Role of Marketing Mix and Service Quality on Tourist Satisfaction and Loyalty at Samosir, Independent Journal of Management ve Production, 10 (5):1662-1678.

Chivandi, A., Samuel, O. ve Muche, M. (2020). The Effect of Online Travel Agencis (OTA) on Brand Relationships in Low and High-End Hotels in South Africa, GeoJournal of Tourism and Geosites, 31 (3): 951-957.

Chung, K. ve Shin, J. (2008). The Relationship Among E-Retailing Attributes, E-Satisfaction and E-Loyalty, Management Review: An International Journal, 3 (1): 23-45.

Çetin, İ. (2009). Otel İşletmelerinde Marka Değeri Ve Turistik Tüketici Satın Alma Davranışlarına Etkisi: Çeşme Örneği. (Basılmamış Doktora Tezi), Dokuz Eylül Ǘniversitesi, İzmir, Sosyal Bilimleri Enstitüsü.

Dick, A. ve Basu, K. (1994), Customer Loyalty: Towards an Integrated Conceptual Framework, Journal of The Academy of Marketing Science, 22 (2): 99- 113.

Dutta, S., Chauhan, R. K. ve Chauhan, K. (20117). Factors Affecting Customer Satisfaction of Online Travel Agencies in India, Tourism and Hospitality Management, 23 (2): 267-277.

Gökdemir, S. ve Erdem, S. H. (2017). Seyahat Acentalarında Internet Kullanımı ve Sosyal Medya, Çanakkale Onsekiz Mart Üniversitesi Uluslararası Sosyal Bilimler Dergisi, 2 (3): 23-38.

Gürbüz, S. ve Şahin, F. (2016). Sosyal Bilimlerde Araştırma Yöntemleri: Felsefe - Yöntem - Analiz. Ankara: Seçkin Kitabevi.

İlhan, M. ve Çetin, B. (2014). LISREL ve AMOS Programları Kullanılarak Gerçekleştirilen Yapısal Eşitlik Modeli (YEM) Analizine İlişkin Sonuçların Karşılaştırılması, Eğitimde ve Psikolojide Ölçme ve Değerlendirme Dergisi, 5 (2): 26-42.

Kayış, A. (2009). Güvenirlik Analizi, Ş. Kalaycı (Ed.) SPSS Uygulamalı Çok Değişkenli İstatistik Teknikleri. (ss. 403-419). Ankara: Asil Yayın Dağıtım Ltd. Şti.

Keller, K. L. (1993). Conceptualizing, Measuring, And Managing Customer-Based Brand Equity, Journal of Marketing, 57 (1): 1-22.

Khamwon, A. ve Nantasuk, M. (2020). Brand Awareness, Online Customer Experience, Brand Engagement, and Brand Advocacy: A Case of Online Travel Agencies, International Journal of Business and Economy, 2 (3):1-8.
Kim, W. G., Ma, X., ve Kim, D. J. (2006). Determinants of Chinese Hotel Customers' E-Satisfaction And Purchase Intentions, Tourism Management, 27 (5): 890-900.

Kocaman, S. ve Güngör, İ. (2012). Destinasyonlarda Müşteri Temelli Marka Değerinin Ölçülmesi ve Marka Değeri Boyutlarının Genel Marka Değeri Üzerindeki Etkileri: Alanya Destinasyonu Örneği, Journal of Alanya Faculty of Business/Alanya İşletme Fakültesi Dergisi, 4 (3):143-161.

Kourtesopoulou, A., Theodorou, S.D., Kriemadis, A. ve Papaioannou, A. (2019). The Impact of Online Travel Agencies Web Service Quality on Customer Satisfaction and Purchase Intentions. İçinde; V. Katsoni, ve M. SegarraOña (Editörler.), Smart Tourism as a Driver for Culture and Sustainability (ss. 343-356). Springer.

Lassar, W., Mittal, B. ve Sharma, A. (1995). Measuring Customer-Based Brand Equity, Journal of Consumer Marketing, 12 (4): 11-19.

Lee, K. W., Han, H. ve Hwang, J. (2017). Developing a Matrix for Assessing Service Ability of US Online Travel Agency Websites, Social Behaviour and Personality: an International Journal, 45 (1): 115-126.

Liu, C. H. ve Fang, Y. P. (2018). Conceptualizing, Validating, and Managing Brand Equity for Tourist Satisfaction, Journal of Hospitality ve Tourism Research, 42 (6): 960-978.

Mahadin, B., Akroush, M. N. ve Bata, H. (2020). The Effects of Tourism Websites' Attributes on E-Satisfaction and E-Loyalty: A Case of American Travellers to Jordan, International Journal of Web Based Communities, 16 (1): 4-33.

Masoomeh, M. (2006). Electronic Satisfaction in Tourism Industry. (Basılmamış Yüksek Lisans Tezi). Luleå: Lulea University of Technology: Faculty of Business Administration.

Matthews, D. R., Son, J. ve Watchravesringkan, K. (2014). An Exploration of Brand Equity Antecedents Concerning Brand Loyalty: A Cognitive, Affective, and Conative Perspective, Journal of Business and Retail Management Research, 9 (1): 26-39.

Niu, L. X. ve Lee, J.H. (2018). The Intention of Repurchase on E-Service Quality by Online Travel Agency Site, The Journal of Industrial Distribution ve Business, 9 (7): 61-70.

Önen, V. (2017). Havayolu Taşımacılı̆̆ında E-Tatmin, E-Sadakat, Ağızdan Ağıza İletişim, Daha Fazla Ödeme İstekliliği Arasındaki İlişkilerin İncelenmesi: Pegasus Havayolları İncelemesi, Uluslararası Sosyal Bilimler Dergisi, 1 (8): 53-67.

Pinar, M. ve Trapp, P. (2010). Brand Ecosystem Strategy for Olive Oil, The Business Review, 15 (2): 67-73.

Porter, M. E. (2001), Strategy and the Internet, Harvard Business Review, 79 (3): 63-78.

Quan, N., Chi, N., Nhung, D., Ngan, N. ve Phong, L. (2020). The Influence of Website Brand Equity, E-Brand Experience on E-Loyalty: The Mediating Role of E-Satisfaction, Management Science Letters, 10 (1): 63-76

San Martin, H., Herrero, A. ve Garcia de los Salmones, M. D. M. (2019). An Integrative Model of Destination Brand Equity and Tourist Satisfaction, Current Issues in Tourism, 22 (16):1992-2013. 
Sarışık, M. ve Özbay, G. (2012). Elektronik Ağızdan Ağıza İletişim Ve Turizm Endüstrisindeki Uygulamalara İlişkin Bir Yazın İncelemesi, Uluslararası Yönetim Íktisat ve İşletme Dergisi, 8 (16): 1-22.

Simon, C. J. ve Sullivan, M. W. (1993). The Measurement and Determinants of Brand Equity: A Financial Appoach, Marketing Science, 12 (1): 28-52.

Tarigan, M. F. (2017). Comparative Study of Brand Equity: (A Case Study of Traveloka.com and Tiket.com) (Basılmamış Doktora Tezi). Cikarang: President University: Faculty of Business.

Ting, C. W., Chen, M. S. ve Lee, C. L. (2013). E-Satisfaction and Post-Purchase Behaviour of Online Travel Product
Shopping, Journal of Statistics and Management Systems, 16 (2-3): 223-240.

Tseng, A. (2017). Why Do Online Tourists Need Sellers Ratings? Exploration of The Factors Affecting Regretful Tourist E-Satisfaction, Tourism Management, (59): 413-424.

Yılmaz, V. ve Varol, S. (2015). Hazır Yazılımlar ile Yapısal Eşitlik Modellemesi: AMOS, EQS, LISREL, Dumlupınar Üniversitesi Sosyal Bilimler Dergisi, (44): 28-44.

Yoo, B., Donthu, N. ve Lee, S. (2000). An Examination of Selected Marketing Mix Elements and Brand Equity, Journal of the Academy of Marketing Science, 28 (2): 195-211.

Zeithaml, V. A. (1988). Consumer Perceptions of Price,Quality, and Value: A Means-End Model and Synthesis of Evidence, Journal of Marketing, 52 (3): 2-22.

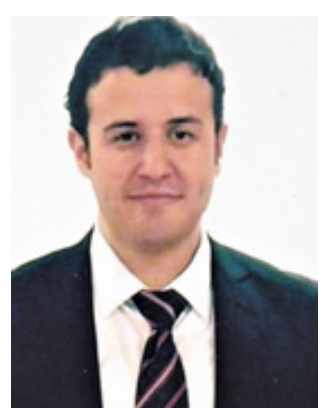

Anıl KÜTÜK

Yaşar Üniversitesi Meslek Yüksekokulu Turizm ve Otel İşletmeciliği Programından Ön lisans derecesini aldı (2011). Ardından Yaşar Üniversitesi İktisadi ve İdari Bilimler Fakültesi Turizm İşletmeciliği Bölümü’nden lisans derecesini aldı (2013). Yüksek lisansını yine Yaşar Üniversitesi Sosyal Bilimler Enstitüsü Turizm İşletmeciliği Anabilim Dalı’nda tamamlayıp, Bilim Uzmanı unvanını aldı (2016). Ardından Dokuz Eylül Üniversitesi Turizm İşletmeciliği Anabilim Dalı Doktora Programı́na başladı (2016). Halen aynı kurumda tez aşamasında Doktora eğitimine devam etmektedir. Çeşitli çalışma alanları; turizm, gastronomi turizmi, turizm pazarlaması, turizmde e-pazarlama, turizmde tüketici davranışları ve markadır.

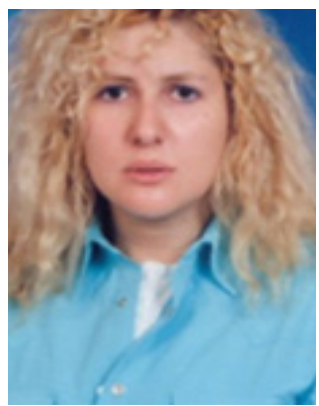

Burcu Selin YILMAZ

Dokuz Eylül Üniversitesi İşletme Fakültesi Turizm İşletmeciliği Bölümü’nden lisans derecesini aldı (1997). Yüksek lisans derecesini yine Dokuz Eylül Üniversitesi Sosyal Bilimler Enstitüsü Turizm İşletmeciliği Anabilim Dalı́ndan aldı (2000). Doktora derecesini ise yine Dokuz Eylül Üniversitesi Sosyal Bilimler Enstitüsü Turizm Iş̧letmeciliği Anabilim Dalı́ndan aldı (2005). Dokuz Eylül İşletme Fakültesinde sırasıyla Yardımcı Doçent (2006), Doçent (2011) ve Profesör (2017) derecelerini aldı. Halen Dokuz Eylül Üniversitesi İ̧̧letme Fakültesi'nde Profesör olarak öğretim üyeliği görevini sürdüren Yılmaz, geçmişten bugüne çok sayıda uluslararası ve ulusal nitelikli araştırmayı (makale, bildiri, kitap bölümü, vb.) alanyazına kazandırmıştır. 